\title{
Climate Variability and Livelihood Diversification in Northern Ethiopia - A Case Study of Lasta and Beyeda Districts
}

DOI:

10.1111/geoj.12178

\section{Document Version}

Accepted author manuscript

Link to publication record in Manchester Research Explorer

Citation for published version (APA):

Weldegebriel, Z. B., \& Prowse, M. (2017). Climate Variability and Livelihood Diversification in Northern Ethiopia A Case Study of Lasta and Beyeda Districts. Geographical Journal, 183(1), 84-96.

https://doi.org/10.1111/geoj.12178

\section{Published in:}

Geographical Journal

\section{Citing this paper}

Please note that where the full-text provided on Manchester Research Explorer is the Author Accepted Manuscript or Proof version this may differ from the final Published version. If citing, it is advised that you check and use the publisher's definitive version.

\section{General rights}

Copyright and moral rights for the publications made accessible in the Research Explorer are retained by the authors and/or other copyright owners and it is a condition of accessing publications that users recognise and abide by the legal requirements associated with these rights.

\section{Takedown policy}

If you believe that this document breaches copyright please refer to the University of Manchester's Takedown Procedures [http://man.ac.uk/04Y6Bo] or contact uml.scholarlycommunications@manchester.ac.uk providing relevant details, so we can investigate your claim.

\section{OPEN ACCESS}




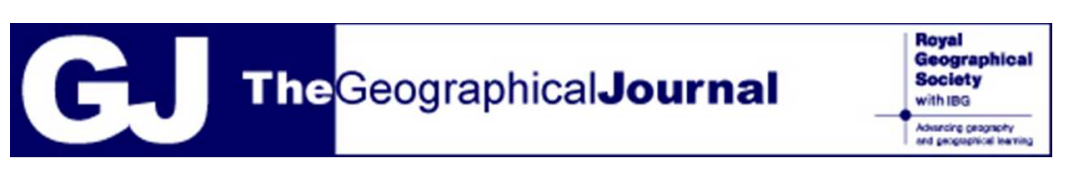

\section{Climate Variability and Livelihood Diversification in Northern Ethiopia - A Case Study of Lasta and Beyeda Districts}

\begin{tabular}{|c|l|}
\hline Journal: & The Geographical Journal \\
\hline Manuscript ID & GJ-RP-Nov-2015-0086.R2 \\
\hline Keywords: & $\begin{array}{l}\text { adaptation, Ethiopia, qualitative methods, livelihood diversification, } \\
\text { smallholders, climate variability }\end{array}$ \\
\hline Abstract: & $\begin{array}{l}\text { This article examines smallholders' perceptions of climate variability in two } \\
\text { districts in Northern Ethiopia, and the diversification options pursued within } \\
\text { and outside agriculture. Meteorological records corroborate smallholders' } \\
\text { belief that temperatures are increasing but do not support assertions that } \\
\text { rainfall is decreasing. Farm-level adaptation mainly involves soil and water } \\
\text { conservation measures learnt from state-led schemes as well as planting a } \\
\text { broader crop mix. Diversification outside agriculture is mainly wage } \\
\text { labour: international and national migration, construction work in local } \\
\text { towns, participation in public works and piecework on nearby farms. The } \\
\text { article concludes by arguing that policymakers could do more to support } \\
\text { non-farm diversification strategies by recognising the importance of rural- } \\
\text { urban connections in fostering adaptation. }\end{array}$ \\
\hline
\end{tabular}




\title{
Climate Variability and Livelihood Diversification in Northern Ethiopia -
} A Case Study of Lasta and Beyeda Districts

\begin{abstract}
This article examines smallholders' perceptions of climate variability in two districts in Northern Ethiopia, and the diversification options pursued within and outside agriculture. Meteorological records corroborate smallholders' belief that temperatures are increasing but do not support assertions that rainfall is decreasing. Farm-level adaptation mainly involves soil and water conservation measures learnt from state-led schemes as well as planting a broader crop mix. Diversification outside agriculture is mainly wage labour: international and national migration, construction work in local towns, participation in public works and piecework on nearby farms. The article concludes by arguing that policymakers could do more to support non-farm diversification strategies by recognising the importance of ruralurban connections in fostering adaptation.
\end{abstract}

KEYWORDS: Ethiopia, adaptation, qualitative methods, livelihood diversification, smallholders, climate variability. 


\section{Introduction}

According to the Climate Change Vulnerability Index, Ethiopia is ranked 7th among countries at risk from the impacts of climate change (Maplecroft 2015). This vulnerability largely emanates from its low level of development and dependence on agriculture - the mainstay of Ethiopia's economy, which contributes $40.2 \%$ of GDP, employs $80 \%$ of its population and accounts for $70 \%$ of export earnings (African Development Bank 2015). Most climate models predict temperatures in Ethiopia will rise over the coming years, increasing by $2.1^{\circ} \mathrm{C}$ in 2050 and $3.4^{\circ} \mathrm{C}$ by 2080 (FDRE 2007). Over the past five decades, rainfall has shown a high degree of variability (ibid.). This is expected to continue, and the frequency and severity of droughts and floods is expected to increase (Deressa et al. 2011). Thus, proactive adaptation strategies are necessary to reduce the impact of climate change on agriculture and to improve resilience. Smallholders' perception of current climate variability and their response through local adaptation measures can serve as useful input for integrated and sustainable adaptation strategies. The strategies smallholders pursue are the result of long-term experience and assessment of risks in their day-to-day production and consumption decisions (Dinar 2008). Policy needs to understand these autonomous adaptation decisions and provide the right incentives for positive and long-term forms of adaptation. In this respect, adaptation to short-term climate variability and extreme events can serve as the basis for reducing vulnerability to longer-term climate change (Baas and Ramasamy 2008; Field 2012). Past experience with agricultural technologies and natural resource management shows smallholders are more likely to adopt new practices when there is a close fit with existing practices and the social/environmental context (Below et al. 2010; Kassie et al. 2013). 
This paper contributes to debates on adaptation by presenting an empirical study from two districts in Northern Ethiopia. Two questions guided the research: To what extent do smallholders' perceptions of climate variability correspond with meteorological data? What forms of diversification are smallholders pursuing? The rest of the paper proceeds as follows. Section 2 provides a literature review on perceptions of climate variability and on local adaptation. Section 3 gives a description of the research sites and research methods. Section 4 presents the results and discussion. This section starts by summarising smallholders' perceptions of climate variability before comparing these to meteorological data. It then describes the effects of climate variability, smallholder diversification within and outside agriculture as well as the sequencing of livelihood activities. The fifth section summarises the conclusions drawn from the research.

\section{Literature review}

Successful adaptation to climate change involves two steps: the perception of changes in climate and taking action in response to the perceived change (Maddison 2007). Many studies do not focus on perception but on the determinants of adaptation using models that combine climatic, biophysical and economic variables (McCarthy et al. 2001). While such studies are important, understanding people's experiences of climate variability is equally relevant: perception is crucial in shaping responses. For example, Adger et al. $(2009,346)$ argue that perception is one factor that constrains or facilitates decision-making for both individual and collective adaptation. This section therefore reviews two groups of studies: first, those that examine perceptions; and second, those that focus on local adaptation strategies.

Perceptions of climate variability 
It is clear that people experience changes in local weather patterns. These may not necessarily reflect long-term local and global trends in the climate. Nevertheless, drawing from behavioural research, many have argued that the perception of changes in the weather can play an important role in adaptation and in supporting climate policy (Howe et al. 2013; Clayton et al. 2015). Research from psychology and environmental psychology conducted in the North reveals the importance of perceived changes in temperature for action. Based on studies in the USA and Australia, Joireman et al. (2010) and Li et al. (2011) found individuals' perception of increased daily temperature correlates with a greater belief in global warming. It also increases the propensity to act. Moreover, based on a survey from 89 countries, Howe et al. (2013) found that most people perceive and adapt to local climatic changes and their perception largely correspond with patterns of observed temperature change from meteorological records. Turning to Africa, based on a survey from 10 African countries (including Ethiopia), Maddison (2007) analysed perceptions of and adaptation to climate variability. The results showed most smallholders perceived an increase in temperature and a decrease in rainfall and implemented some adaptation measures within existing institutional and financial constraints (see also Di Falco and Veronesi 2014).

There are only a small number of studies that focus on perceptions of climate change specifically in Ethiopia. Based on qualitative data from group and in-depth interviews in Northern Ethiopi, Meze-Hausken (2004) found smallholders strongly perceived a change in the climate even when meteorological records showed no reduction in total rainfall. A further study, by Deressa et al. (2011), applied the Heckman selection model to a sample of 1,000 households in five regions and found smallholders' perceptions of climate variability are related to age, wealth, social capital, access to information and agro-ecological settings. A more recent study by Kassie et al. (2013) examined farmers' perception in the Central Rift 
and Kobo Valley areas based on a household survey of 200 farmers, interviews and group discussions. The findings showed smallholders in both areas perceived a change in their local climate and implemented various on-farm adaptation strategies, in particular by changing their crop mix. This brings us to our review of studies in Ethiopia that focussed on local adaptation.

Local adaptation to climate variability

Much of the empirical literature on rural Africa focuses on agricultural technology adoption. Although the importance of such adaptation measures is undeniable, it is debateable whether such technologies are easily accessed by the majority of smallholders in Africa. Moreover, as smallholder agriculture is highly sensitive to climate conditions, it is difficult to predict which technology is useful in a locality since climatic models do not predict scaled-down changes let alone threshold effects and non-linear changes in systems (Cannon 2014; Seo and Mendelsohn 2007).

Numerous studies suggest it is important to consider the autonomous adaptation practices that rural communities are implementing (see Cooper et al. 2008; Forsyth and Evans 2013; Campos et al. 2014). Strategies in smallholder agriculture often involve switching crop varieties and livestock species (Seo and Mendelsohn 2007), the use of irrigation, greater crop diversification and changing planting dates (Bauer and Scholz 2010; Mertz et al. 2009; Gebrehiwot and Venn 2013).

Previous studies on climate change in Ethiopia have focused on measuring the impact of climate change on agriculture (see Deressa 2007; Hailemariam 1999). These studies analysed the monetary impacts of climate change using Ricardian and agronomic models and 
suggested water harvesting and irrigation as key adaptation options. However, such studies are limited in terms of offering insights into adaptation strategies at the micro level, because of their aggregate nature (Falco et al. 2011). The number of studies that have investigated local adaptation strategies are limited (Gebrehiwot and Venn 2013; Kassie et al. 2013; Legesse et al. 2013).

Gebrehiwot and Venn (2013) studied farm-level adaptation to climate change in Tigray, northern Ethiopia. Using a multinomial logit model and data from 400 smallholders, they found that the majority of farmers perceived an increase in temperature and a decrease in rainfall in the last two decades which matched climatic data. However, only half of the farmers that reported changes responded by adopting new strategies (including crop diversification, soil conservation, irrigation, planting trees and changing planting dates). Legesse et al. (2013) conducted a survey of 160 households from Doba district in Eastern Ethiopia and applied a multinomial logit model to identify factors influencing adaptation strategies. They found crop and livestock diversification, soil and water conservation practices, off-farm activities (such as piecework and harvesting natural resources) and rainwater harvesting as the dominant adaptation strategies. This study aims to complement these studies by offering an explicit focus on non-farm forms of livelihood diversification (see also D'Haen et al. 2014, 1). The Kassie et al. (2013) study is described above. We now turn to the research sites and research methods for this study.

\section{Research sites and research methods}


The study was conducted in Lasta and Beyeda districts of Amhara National Regional State, Northern Ethiopia. These districts were chosen due to their livelihood and vulnerability profiles which we now describe in turn. The two districts are part of different livelihood zones: Lasta comprises mainly the North East Mixed Cereal Livelihood Zone where the key crops are sorghum, teff, barley and wheat alongside legumes. Beyeda mostly consists of the North Highland Wheat, Barley and Sheep Livelihood Zone which is a mixed farming system dominated by wheat, barley, beans and livestock. Turning to vulnerability profiles, both districts are classified as food insecure and are served by the Productive Safety Net Programme (PSNP - see Weldegebriel and Prowse 2013). Beyeda faces food deficits every year. Almost all farmers depend on food purchases and food aid makes an important contribution to consumption for many households. Lastly, both districts have extreme climatic conditions. Lasta frequently suffers from droughts and was at the centre of famine in the mid-1980s. Beyeda is located in the foothills of the highest mountain range in Ethiopia with temperatures ranging from werich (very cold) to weyna dega (moderate). A full comparison of biophysical and socio-economic characteristics is presented in Table 1.

$<$ Table 1 around here $>$

In terms of research methods, the study followed a broadly inductive approach to data collection. Fieldwork took place between May to August 2013 and included semi-structured interviews with key informants, focus group discussions and direct field observation. ${ }^{1}$ Moreover, participatory techniques such as wealth-ranking exercises, historical timelines, seasonal calendars, transect walks and a problem-ranking matrix were conducted with smallholders in Lasta. 
Smallholders' perception of climate variability and change were compared with rainfall and temperature records obtained from the nearest meteorological stations of Lalibela (for Lasta) and Debark for Beyeda (both run by the National Meteorological Agency). These data were monthly records of rainfall and maximum and minimum temperature for the period 19892011 for Lasta and 2000-2011 for Beyeda. Rainfall variability was calculated using the coefficient of variation (CV) on both a year-to-year basis (inter-annual variability) and for the whole period. Linear regressions and Mann-Kendall (non-parametric) trend tests were used to detect trends on temperature and rainfall data. We now turn to the results and discussion. As described above, this is split into four sections starting with smallholders' perceptions of climate variability and a comparison with meteorological records.

\section{Results and discussion}

Respondents in both districts stated they perceived increased temperatures and erratic rainfall patterns in the last two decades. We report results from Lasta before turning to Beyeda. In Lasta, respondents described a warming trend in the past five years with both minimum and maximum temperatures increasing. They also offered local indicators to support this increase in temperature: that smallholders used to wear locally-knitted clothes thick and warm enough to be used as blankets (koborta and gabi), now they use a very light cloth (netella). And that whilst fifteen years ago, injera used to stay fresh for 4 to 5 days it now becomes mouldy in 2 days. $^{2}$ 
Respondents from Lasta stated that the short March - May rains (belg) are becoming more erratic and unreliable for crop production. The famine year of 1984 is frequently mentioned as a turning point for these changes. Smallholders in Lasta have relied heavily on belg rains for growing sorgum, millet and maize (referred to locally as belage). In addition to the changes in belg rains, participants in Lasta highlighted how precipitation is coming late and stopping early during the main rainy season (kiremet). Two or three decades ago, kiremet rains used to start as early as $12^{\text {th }}$ June and finish in mid-September. Kiremet rains now arrive later, are erratic and stop earlier, sometimes in mid-August. Respondents referred to kiremet rains as a 'fickle friend'. When referrring to longer-term changes in the climate, smallholders in Lasta referred to land becoming berha which can be translated as 'desert, unsuitable for both farming and livestock rearing'. This is a strong indication that farmers believe unusual weather patterns will lead to non-linear changes in agro-ecological conditions.

In Beyeda, respondents stated that changes in temperature are a recent and abrupt phenomenon. According to group discussions, for much of the dry bega season, they experience several days with temperatures oscillating between cold (in the mornings) and very hot (in the afternoons). Such conditions are very different from ten years ago. Respondents also offered local indicators of changes in the climate. For example, beer brewers are finding that during the dry season, their product, tella (prepared from barley, hops and spices), is fermenting at too high a temperature which imparts a harsh taste. Similar rainfall trends are reported as in Lasta with greater variability in the pattern of rains in both belg and kiremet seasons.

Respondents in both areas also highlighted an increase in extreme climatic events. In Lasta participants of both focus group discussions almost unequivocally agreed that since the mid- 
1990s droughts now occur every three to five years. In Beyeda, respondents focused on greater intensity of rainfall leading to frequent flash floods which aggravates land degradation. These reponses from smallholders were corroborated by interview data from key informants in district offices. We now turn to the analysis of meteorological data.

Meteorological data

Meteorological data for Lasta recorded rainfall and temperature measurements since 1989 with a brief interruption during the change in regime from 1990-1991. For Beyeda, records from Debark station were only available for the period 2000-2011. Temperature and rainfall data for the Debark station prior to the year 2000 are patchy with many missing data points and are unsuitable for trend analysis. The maximum and minimum mean temperatures across years for Lasta are shown in Figure 1. These data show a greater increase in the former than the latter. The mean maximum temperature in Lasta has increased by about $0.0350 \mathrm{C}$ every year during the years 1989-2011 indicating a warming trend over the past two decades. Figure 2 shows the data for Beyeda. Here, maximum average temperature shows an increasing trend (increased by $0.050 \mathrm{C}$ per year) while the minimum temperature did not show a marked trend. We implemented a linear regression model to test the existence of a trend for temperature and rainfall data and then used the Mann-Kendall trend test on data that have shown a reasonably high R-squared value to check for statistical significance. ${ }^{3} \mathrm{~A}$ significant trend was detected for the annual mean maximum temperature data from the two districts (at the 99\% level). The trends with their linear regression equations and coefficient of determinations (R2) are summarized in Table 2. 
The figures on rainfall are shown in Table 3. Here we find no increases or decreases in total rainfall in either Lasta or Beyeda $\left(\mathrm{R}^{2}=0.0001\right.$ and 0.0223 , respectively). In addition, recent trends in belg and kiremet rains in Lasta do not show any marked changes. However, in Beyeda, kiremet rains are stable over the period (2000-2011) while, interestingly, belg rains show a slightly increasing trend $\left(\mathrm{R}^{2}=0.27, \mathrm{p}<0.10\right)$.

$<$ Table 2 around here $>$

$<$ Table 3 around here $>$

Moreover, rainfall data also show interesting changes in variation around the mean. We use the coefficient of variation because we require a relative and not absolute measure of dispersion. The data for Lasta (1989-2011) showed moderate inter-annual variation based on a range of $338-1002 \mathrm{~mm}(\mathrm{CV}=26.3 \%)$. Rainfall in the belg season shows greater variability within a range of $23-310.9 \mathrm{~mm}(\mathrm{CV}=61 \%)$. The kiremet rains showed moderate variation with a range of $153.4-893.6 \mathrm{~mm}(\mathrm{CV}=34.5 \%)$. Overall, these data suggest a small degree of compensation between seasons: in other words, rainfall shortages in the belg tend to be slightly compensated for through greater amounts of kiremet rain.

In Beyeda, inter-annual rainfall variation is less than Lasta and has a tighter range of 810 $1357 \mathrm{~mm}(\mathrm{CV}=14.4 \%)$. Belg rainfall also displays less variation than Lasta within a smaller range of $41.2-219.6 \mathrm{~mm}(\mathrm{CV}=54 \%)$ as does the kiremet rainfall (which ranged between 740- 
$1198 \mathrm{~mm}-\mathrm{CV}=13.8 \%$ ). In Beyeda capricious belg rains appear to be compensated by more stable kiremet seasons.

Rainfall anomalies (defined as deviations from the ten and twenty-one year mean rainfall figures for Lasta and Beyeda, respectively) compared to moving averages are given in Figures 3 and 4. In neither district does total annual rainfall show an increasing in the anomalies over time; rather, their distributions remain relatively stable with the number of deficit years more or less equalling those with above-average rainfall.

To summarise, then, the analysis of rainfall and temperature records shows maximum temperatures to be increasing, while there is no apparent decline in rainfall amount. The data also show greater rainfall variation in Lasta than Beyeda. Moreover, they show greater variation in thebelg than in the main kiremet season in both districts. This last result chimes with climatological studies that have analysed long periods of rainfall and temperature trends in Ethiopia (Conway et al. 2004; Seleshi and Zanke 2004).

Comparison of meteorological data with smallholders' perceptions

Whilst maximum temperature records are consistent with smallholders' perceptions of higher temperatures in both districts, rainfall data show no significant decline which, overall, conflicts with smallholders' assertions. This tension is most severe when we compare those years highlighted by smallholders as drought years. In Lasta, both 2002 and 2005 were highlighted as a drought year, but the rainfall records show that both belg and kiremet seasons had average rainfall in 2002 and higher-than-average in 2005. In contrast, the more recent rainfall deficit, in 2010, was not flagged by smallholders as an extreme year. 
There are different ways of interpreting these discrepancies. One is that the spatial distribution of rainfall was such that the experience of participants did not correlate well with that of the meteorological stations. This highlights the deficiencies of such a small-n qualitative study and the lack of observations within the meteorological data. A further interpretation is that farmers responded to the low rainfall in 2001 and 2004 to categorize 2002 and 2005 as drought years. One final interpretation is that the discrepancy highlights an important but subtle difference between farmers' perceptions and climate records; namely, that farmers' perceptions are heavily influenced by irregularities in the patterns of rain - the onset, duration and cessation - rather than by the amount of rain. Such information is lacking in aggregate rainfall records.

Effects of climate variability

The effects of climate variability are discussed here in terms of agriculture, livestock, disease and social reproduction, beginning with agriculture. Respondents in Lasta highlighted how the frequentdry spells in the rainy season are affecting teff yields, which have declined in recent years. The late onset of belg rains was also highlighted as a key factor in the reduced production of millet and sorghum. Focus group discussion participants from Beyeda indicated a different set of challenges: hail storms and frost, coupled with more erratic rains, are damaging barley and wheat crops. In both districts, all key informants highlighted that the increase in temperature along with variability in rainfall poses a risk to their livelihoods. 
In Lasta, all respondents in focus groups mentioned an increase in livestock diseases associated with increasing temperatures and a lack of water. Some respondents explained how higher temperature can create more favourable conditions for the spread of skin diseases amongst cattle. Key informants suggested a slightly different mechanism for the greater incidence of disease: namely that changes in climatic conditions reduce the availability of fodder and water, leading to greater contamination of different herds. Examples include infestations of tick-borne diseases that cause lumpy skin disease (gureb-reb), foot-and-mouth disease and anthrax (aba-senga). Respondents in Lasta also highlighted less human morbidity from the new climatic variability: that malaria incidence in low-lying (kola) villages had showed a marked reduction in recent years. Respondents related this to the frequent dry spells and shortages of rainfall. Lastly, women highlighted how higher temperature means that food (injera and stew) has to be consumed immediately now, placing a greater burden on women and girls who expend more energy on cooking more frequently. Moreover, the greater distance to collect water has further increased the social reproductive burden they carry. The main impacts of climate variability on livelihoods are summarized in Table 4 . We now turn to diversification within agriculture before turning to diversification outside agriculture.

$<$ Table 4 around here $>$

\section{Diversification as an adaptation strategy}

Climate variability forces farming communities to adapt to dynamic environmental conditions. The maintenance of a diversified resource or income base helps reduce vulnerability by spreading risk (Kelly and Adger 2000; Macchi et al. 2008,18). In view of this, we examine livelihood diversification strategies in both districts. As in the case for most rural parts of Ethiopia, smallholders in the districts rely largely on mixed agriculture i.e. crop 
and animal husbandry. Here, however, we discuss two broad categories of diversification; within and outside agriculture.

\section{Diversification within agriculture}

The role of farm diversification on the viability and vitality of agriculture is well documented (Barnes et al. 2015; Hansoon et al. 2013). In the context of climate adaptation, the use of crop varieties and livestock species well-suited to drier conditions, irrigation, crop diversification, and changing planting dates are idenified as the most common adaptation methods (Bradshaw et al. 2004; Hassan and Nhemachena 2008; Kurukulasuriya and Mendelsohn 2006).

In Lasta, on-farm diversification takes two forms. First, participants in the Productive Safety Net Programme (PSNP), which conducts water and soil conservation measures (such as creating terraces, check-dams and afforestation measures) on public land (common pool resources), also apply such measures on their own land. This leads to a more diversified cropping system. A good example is shown in Box 1. For example, in recent years smallholders have started to harvest rainwater to irrigate land and to grow perennial crops and trees instead of cereals. Second, bee-keeping has been encouraged by local government through training sessions and credit. ${ }^{4}$ This has had some success with smallholders supplying honey to Lalibela town. In Beyeda, respondents have started planting early-maturing varieties of barley (used as malt for brewing beer). But according to one key informant, such on-farm diversification is only undertaken by a handful of model farmers. A further form of crop diversification is growing eucalyptus trees for sale. Discussions with key informants revealed that because of attractive prices for eucalyptus trees and gesho (hops) at the local market, 
many farming households have recently begun to harvest rainwater to irrigate their land (see Box 1). Some have shifted from cereals to growing perennial crops and trees. Similar rainwater harvesting techniques are found to be the most popular adaptive strategies among smallholder farmers in South Africa (see Gandure et al. 2013). This finding also chimes with Di Falco and Chavas' (2009) investigation of how the genetic diversity of crops contributes to farm productivity and reduces the cost of weather risks.

Box 1 - A case of successful smallholder adaptation

Amanuel Bereket, a priest in a local Degosach parish, Lasta, is a father of 6 children. He was born in the same village and recalls two devastating droughts and the resulting famines. He remembers losing two of his close relatives in the 1984 famine. He owns one hectare which he uses to grow teff. He claims his experience of the frequent droughts and crop failures has thought him a good lesson on the need to harvest and conserve water. He first voluntered part of his farmland for a model water-harvesting schemes, and then learnt the skills to use and maintain the well. Later on, he dug up another two water-wells in his yard and began to grow fruits and vegetables on a small patch of land. After five years of hard work, he was able to save money that he used to borrow land from other farmers and started breeding sheep, beekeeping and growing gesho (hops) as a cash crop. Now, he owns a local shop/kiosk and hopes to expand his business.

\section{Diversification outside agriculture}

Diversification away from farming one's own land is driven by multiple processes including changing landholding patterns and demand for non-farm goods and services. It creates opportunities for accumulation as well as cushioning smallholders from losses due to climatic variability (Debela et al. 2014). Although the role of non-farm diversification within the rural development is very well-documented, there is less discussion within the adaptation 
literature (see Cannon 2014). Thus, there are only a few studies that demonstrate the positive role of diversification away from farming as an adaptive strategy. For instance, Bryan et al. (2009) demonstrate how non-farm activities have the most positive effect in encouraging adaptation options in agricultural livelihoods in Ethiopia and South Africa (see Bryan et al. 2009). Diversification outside agriculture may also occur either as a deliberate household strategy (by design) or as an involuntary response to a crisis (by default) (Ellis 1998). The former usually involve non-farm activities in manufacturing or service sectors, whilst the latter are often termed off-farm activities and include piecework on other farmers' land or harvesting natural resources.

Overall, in both districts, diversification away from seasonal agriculture can be broadly categorized in line with Warren's (2002) classification: a wage labour path and a selfemployment route. We discuss the findings from Lasta before turning to Beyeda. We conclude the section by discussing the sequencing of diversification strategies.

Respondents in Lasta highlighted the limited opportunities for diversifying livelihoods into non-farm activities in their villages. Existing diversification strategies are to a large extent seasonal and depend on demographic characteristics (mainly age and gender) and wealth group. Key informants explained that as belg rains are becoming unreliable and belg agricultural production is now uncertain, young adults tend to engage in seasonal migratory wage labour to neighbouring regions: to Raya for agricultural wage labour and sometimes as far as Humera for commercial sesame production. Young adults who have family obligations, such as elderly parents or young children, prefer to engage in daily wage labour (shekel) in nearby Lalibela town mostly in the burgeoning construction sector that pays a daily rate of 35-40 Birr. 
The poorest households also engage in wage labour, especially in the government's public works activities (the PSNP) and/or in local piecework (weeding, harvesting, threshing) within their village (a form of off-farm activity). Some better-off households engage more in selfemployment, especially in more profitable non-farm activities such as trading oxen, sheep and goats.

Respondents also revealed that household participation in other forms of self-employment such as carpentry, masonry or by working as a blacksmith can, as this is manual work, carry a certain social stigma. This can also be the case for petty trading through preparing and selling local food and alcoholic beverages, activities which are mostly pursued by women-headed households (who often lack land, oxen and enough household labour for farming).

Most non-farm activity occurs in the months outside the growing seasons (mainly OctoberDecember). This not only indicates the timing of greatest annual demand for non-farm goods and services, but highlights the competition for household labour between farm-based and non-farm based livelihood strategies. Households thus have to make decisions about how to allocate labour resources efficiently: how to engage in non-farm and off-farm activity without jeopardising farm production. A good example of this concerns the public works component of the PSNP. Here, participants are expected to contribute labour for six months within their village. As a result, many poor farmers prefer to engage in locally available off-farm activities rather than engaging in non-farm activities elsewhere. A good illustration of the range of wage employment available in Lasta can be gleaned from Box 2.

Box 2 - One farmer's view on wage employment as a form of diversification 
Kassalem Mulugeta, 35, is from Medage village, Lasta district, he is married and has two children. He completed the $6^{\text {th }}$ grade of education.

"I have less than half a hectare of land that I mostly use to cultivate wheat. In the last meher season, I only managed to harvest $150 \mathrm{kgs}$, not enough to feed my family for four months. Therefore, I consider myself poor, though slightly better than those who do not have either farmland or able-bodied family members. Since my income from agriculture is barely enough, I always try to earn extra income by engaging in non-farm activities a few months outside the agriculture season. I am participating in the public works programme and contribute labour to terracing and check-dam construction. Most of the activities involve hard physical labour and one has to work for 15 days per month to earn 19.5 Birr per day. This payment is given in cash for two months and in-kind for four months. I consider the public work payment very low, but I am not complaining, because I consider it to be a way out of misery for farmers like myself who are able-bodied and healthy. I always dream of going to the big cities like Desse and Addis Ababa to work hard, earn more and live a decent life but I cannot afford that because my kids are too young and I have to support my ailing mother. The public works last until the end of June. After the rainy season, I take on locally available labour usually in harvesting and threshing [off-farm], earning some cash which I use to cover some expenses. The wage rate for such activities varies and depends on the employer's discretion ranging from 20-30 Birr per day. Occasionally, I travel to Lalibela and look for wage labour mostly in the construction of houses and buildings earning 35 to 40 Birr per day".

Compared to Lasta, livelihood diversification in Beyeda is more limited with few opportunities for smallholders to engage in different activities. In terms of wage employment, seasonal migration for sesame production (to Humera) is common. Participants highlighted how the lack of credit and infrastructure (including an all-weather road and market place) were key obstacles in pursuing non-farm activities, especially trading. Cultural barriers were also mentioned as limiting farmers' participation in manual self-employment. These cultural impediments also extend to renting mules to tourists and their scouts. Mule ownership has 
long been a status symbol in some of the remotest villages but renting-out mules to tourists can be frowned upon by villagers as an undignified way of earning income. It is important to note that in both districts respondents did not volunteer information about one off-farm activity that was widepsread - charcoal production - as this is illegal.

Sequences of livelihood strategies

Although surpluses generated from non-farm activities can provide farmers with income for on-farm investment, interviews with key informants revealed that little income generated from non-farm activities is reinvested into farming. It seems that households are only able to reinvest in agriculture when non-farm work is short-term and the farm work is not constrained by a shortage of land, oxen or any other input. Otherwise, smallholders tend to engage in non-farm activities to earn cash to ensure the household's access to food and so smooth consumption until the next harvest season. Key informants also disclosed that earnings from non-farm activities are often used to repay debt or finance social and cultural events such as marriage and tezkar - a memorial feast for a deceased family member.

In sum, diversification away from agriculture is highly seasonal and largely follows a wage path rather than a self-employment path. Wage labour is the dominant diversification activity in both districts with smallholders constrained in their ability to enter self-employment due to a lack of regular demand, skills, finance as well as cultural attitudes.

Within the wage path, we see two tracks. On the one hand, asset-poor households (lacking land and oxen, and often with a large family size) engage in sharecropping arrangements (where labour is exchanged for a portion of the harvest) and piecework (on neighbours' land) rather than sending able-bodied members in search of better opportunities further afield (a 
form of risk aversion which maintains security in the short term but reduces the likelihood of accumulation in the long term). On the other hand, wealthier households send houshold members further but with clear intra-generational issues. Young adults in such households are keen to engage in the non-farm sector outside their village and demand resources from their household to cover the costs of migration. However, household heads are often reluctant to invest in migration (to places as far as Saudi Arabia) not only because it is costly but also they are unsure if they will receive regular contributions to the household in the form of remittances. Some studies suggest that weather anomalies are likely to increase rural-urban and international migration in sub-Saharan Africa. For example, Marchiori et al. (2012) predict that the net environmental migration in response to climatic anomalies in Ethiopia ranging between 5.21 to 7.38 (per thousand of population) from 2000 to 2099 , which is the highest in the region.

Moreover, the findings from the two districts clearly reflect the role of location. Despite both districts being major tourist destinations, the proximity to Lalibela town and access to roads and markets to bigger cities such as Dessie and Bahir Dar seem to be the decisive factors in opening-up opportunities for pursuing diversified livelihoods in Lasta district. Improving access to infrastructure appears to be a good avenue for promoting the non-farm rural economy in both districts.

\section{Conclusion}

This article has examined perceptions of and adaptation to climate variability and change in two districts in Northern Ethiopia. It has examined the extent to which smallholders diversify 
within and outside agriculture. We have found that whilst meteorological records support smallholders' perceptions regarding an increase in temperatures, claims of a reduction in rainfall is not reflected in meteorological records: highly variable belg rains are compensated for by more stable kiremet rains. Most of the adaptation within agriculture comes through demonstration effects from state-led schemes whilst diversification away from farming is mainly wage labour differentiated by wealth group.

There are subtle but important differences between the two districts that highlight the role of both climatic and non-climatic factors in adaptive capacity. Livelihood diversification in Beyeda is more limited than in Lasta where non-farm diversification appears to be growing due to the proximity to urban opportunities and a construction boom (triggered by public investments). But within Lasta a wide range of factors such as asset holdings and sociodemographic considerations such as household size, education, skills and cultural attitudes influence the choice of diversification strategy at the household level. Many broad socioeconomic factors are framing adaptation pathways at the local level.

On a wider note, our findings highlight how the source of demand for non-farm diversification may well be found outside agriculture. Higher temperatures and more variable rainfall patterns associated with climate change mean it is likely there will be less fertile agricultural land available. In this context, the ability to increase land productivity to stimulate consistent and stable agricultural growth will become increasingly difficult, limiting incomes and demand for non-farm items (e.g. from vending, petty trading, provision of everyday services).

Our limited data from Northern Ethiopia suggests that non-farm diversification is occurring mainly through wage labour: international, national and regional for wealthier households, 
1

2

3

4

5

6

7

8

9

10

11

12

13

14

15

16

17

18

19

20

21

22

23

24

25

26

27

28

29

30

31

32

33

34

35

36

37

38

39

40

41

42

43

44

45

46

47

48

49

50

51

52

53

54

55

56

57

58

59

60 local and on public works schemes for poorer households. In this context, policymakers could do worse than look more at how urban-rural connections can support smallholders' adaptation efforts. 


\section{References}

Adger W N, Dessai S, Goulden M, Hulme M, Lorenzoni I, Nelson D R, Naess LO, Wolf J and Wreford A 2009 Are there social limits to adaptation to climate change? Climatic Change 93 335-354

African Development Bank (AfDB) 2015 Ethiopia Economic Outlook - African Development Bank (http://www.afdb.org/en/countries/east-africa/ethiopia/ethiopiaeconomic-outlook) Accessed 26 January 2016

Baas S and Ramasamy S 2008 Community based adaptation in action Case Study Bangladesh Food and Agriculture Organization of the United Nations/Department of Agriculture Extension, Rome/Dhaka

Bauer S and Scholz I eds 2010 Adaptation to Climate Change in Southern Africa: New Boundaries for Development Earth scan

Below T, Artner A, Siebert R and Sieber S 2010 Micro-level practices to adapt to climate change for African small-scale farmers. A Review of Selected Literature Environment and Production Technology Division

Bryan E, Deressa T T, Gbetibouo G A and Ringler C 2009 Adaptation to climate change in Ethiopia and South Africa: options and constraints Environmental Science and Policy 12 413-426

Campos, M, Velázquez A and McCall M 2014 Adaptation strategies to climatic variability: A case study of small-scale farmers in rural Mexico Land Use Policy 38 533-540

Cannon T 2014 Rural Livelihood Diversification and Adaptation to Climate Change in Ensor J, Huq $\mathbf{S}$ and Berger $\mathbf{R}$ eds Community-Based Adaptation to Climate Change: Emerging Lessons Practical Action Publishing, Rugby

Cheung W H, Senay G B and Singh A 2008 Trends and spatial distribution of annual and seasonal rainfall in Ethiopia International Journal of Climatology 28 1723-1734

Clayton S, Devine-Wright P, Stern P.C, Whitmarsh L, Carrico A, Steg L, Swim J and Bonnes M 2015 Psychological research and global climate change Nature Climate Change 5 640-646

Conway D, Mould C and Bewket W 2004 Over one century of rainfall and temperature observations in Addis Ababa Ethiopia International Journal of Climatology 24 77-91

Cooper P J M, Dimes J, Rao K P C, Shapiro B, Shiferaw B and Twomlow S 2008 Coping better with current climatic variability in the rain-fed farming systems of sub- 
Saharan Africa: An essential first step in adapting to future climate change? Agriculture, Ecosystems \& Environment 126 24-35

Debela B L, Shively G and Holden S T 2014 Does Ethiopia's Productive Safety Net Program Improve Child Nutrition? SpringerPlus 4236

Deressa T 2007 Measuring the economic impact of climate change on Ethiopian agriculture : Ricardian approach, Policy Research Working Paper Series No. 4342, The World Bank

Deressa T, Hassan R M and Ringler C 2011 Perception of and adaptation to climate change by farmers in the Nile basin of Ethiopia The Journal of Agricultural Science 14923 31

D'Haen S L, Nielsen J Ø and Lambin EF 2014 Beyond local climate: rainfall variability as a determinant of household nonfarm activities in contemporary rural Burkina Faso Climate and Development 6 144-165

Dinar A 2008 Climate Change and Agriculture in Africa: Impact Assessment and Adaptation Strategies, Earthscan

Di Falco S and Chavas J-P 2009 On crop biodiversity, risk exposure, and food security in the highlands of Ethiopia American Journal of Agricultural Economics 91 599-611

Di Falco S and Veronesi M 2014 Managing environmental risk in presence of climate change: the role of adaptation in the Nile Basin of Ethiopia Environmental and Resource Economics 57 553-577

Ellis F 1998 Household strategies and rural livelihood diversification Journal of Development Studies 35 1-38

Field C B 2012 Managing the risks of extreme events and disasters to advance climate change adaptation: special report of the intergovernmental panel on climate change, Cambridge University Press, Cambridge

Forsyth T and Evans N 2013 What is Autonomous Adaption? Resource Scarcity and Smallholder Agency in Thailand World Development 43 56-66

Gandure S, Walker S and Botha J J 2013 Farmers' perceptions of adaptation to climate change and water stress in a South African rural community Environmental Development, Thematic Issue - Climate change risk management in Africa 5 39-53

Gebrehiwot T and Venn A van der 2013 Farm Level Adaptation to Climate Change: The Case of Farmer's in the Ethiopian Highlands Environmental Management 52 29-44

Hailemariam K 1999 Impact of climate Change on Water Resources of the Awash Basin, Ethiopia Climate Research 12 91-96 
Howe P D, Markowitz E M, Lee T M, Ko C Y and Leiserowitz A 2013 Global perceptions of local temperature change Nature Climate Change 3 352-356

Kassie B T, Hengsdijk H, Rötter R, Kahiluoto H, Asseng S and Ittersum M V 2013 Adapting to Climate Variability and Change: Experiences from Cereal-Based Farming in the Central Rift and Kobo Valleys, Ethiopia Environmental Management $521115-1131$

Kelly P M and Adger W N 2000 Theory and practice in assessing vulnerability to climate change and Facilitating adaptation Climatic Change 47 325-352

Legesse B, Ayele Y and Bewket W 2013 Smallholder Farmers' Perceptions and Adaptation to Climate Variability and Climate Change in Doba District, West Hararghe, Ethiopia. Asian Journal of Empirical Research 3 251-265

Li Y, Johnson E J and Zaval L 2011 Local warming daily temperature change influences belief in global warming Psychological Science

Macchi M, Oviedo G, Gotheil S, Cross K, Boedhihartono A, Wolfangel C and Howell M 2008 Indigenous and Traditional Peoples and Climate Change Gland, Switzerland IUCN

Maddison D 2007 The perception of and adaptation to climate change in Africa, Policy Research Working Papers The World Bank Washington D.C

Maplecroft 2015 Climate Change Vulnerability Index 2015, Maplecroft's Climate Change and Environmental Risk Atlas (CCERA) Maplecroft, United Kingdom

Marchiori L, Maystadt J F and Schumacher I 2012 The impact of weather anomalies on migration in sub-Saharan Africa Journal of Environmental Economics and Management 63 355-374

McCarthy J 2001 Climate Change 2001: Impacts, Adaptation, And Vulnerability Contribution of Working Group II to the Third Assessment Report of the Intergovernmental Panel on Climate Change, Cambridge University Press, Cambridge

Mertz O, Mbow C, Reenberg A and Diouf A 2009 Farmers' Perceptions of Climate Change and Agricultural Adaptation Strategies in Rural Sahel Environmental Management 43 804-816

Meze-Hausken E 2004 Contrasting climate variability and meteorological drought with perceived drought and climate change in northern Ethiopia Climate Research 2719 31

Río S, Herrero L, Fraile R and Penas A 2011 Spatial distribution of recent rainfall trends in Spain (1961-2006) International Journal of Climatology 31 656-667 
Seleshi Y and Zanke U 2004 Recent changes in rainfall and rainy days in Ethiopia International Journal of Climatology 24 973-983

Seo S N and Mendelsohn R 2007 Climate change adaptation in Africa: a microeconomic analysis of livestock choice, Policy Research Working Papers, The World Bank

Warren P 2002 Livelihoods diversification and enterprise development An Initial Exploration of Concepts and Issues Livelihood Support Programme (LSP) Working Paper 4

Weldegebriel Z B and Prowse M 2013 Climate-Change Adaptation in Ethiopia: To What Extent Does Social Protection Influence Livelihood Diversification? Development Policy Review 31 35-56

Yue S and Hashino M 2003 Temperature trends in Japan: 1900-1996 Theoretical and Applied Climatology 75 15-27 
Figure 1 - Maximum and Minimum Temperature in Lasta, 1989-2011.

Source: NMA data from 1989-2011 
Figure 2 - Maximum and Minimum Temperature in Beyeda, 2000-2011

Source: NMA data from 2000-2011 
Figure 3 - Anomalies in annual rainfall in Lasta, 1989-2011

Source: NMA data from 1989-2011

Notes:

The dotted line shows anomalies of annual rainfall compared to the 21-year mean rainfall (1989-2011) period. The solid line shows a five-year moving average. 
Figure 4 - Anomalies in annual rainfall in Beyeda, 2000-2011

Source: NMA data from 2000-2011

Notes:

The dotted line shows anomalies of annual rainfall compared to the 10-year mean rainfall (2000-2011) period. The solid line shows a two-year moving average. 
Table 1 - Biophysical and socio-economic characteristics of study areas

\begin{tabular}{|c|c|c|}
\hline Characteristics & Lasta & Beyeda \\
\hline \multicolumn{3}{|l|}{ Biophysical characteristics } \\
\hline Altitude & $1400-4200$ & $1900-4437$ \\
\hline Annual mean temperature $\left({ }^{\circ} \mathrm{C}\right)$ & $16-21$ & $8-20$ \\
\hline Annual mean rainfall $(\mathrm{mm})$ & $600-900$ & $1172-1700$ \\
\hline Dominant soil type & Leptosol and Vertisols & Vertisols \\
\hline Topography & $50 \%$ mountainous & $70 \%$ mountainous \\
\hline \multicolumn{3}{|l|}{ Socioeconomic characteristics } \\
\hline Total population (2012) & 129,464 & 105,482 \\
\hline Area in $\mathrm{km}^{2}(2012)$ & $1119.35 \mathrm{~km}^{2}$ & $973.05 \mathrm{~km}^{2}$ \\
\hline Population density (per $\mathrm{km}^{2}$ ) & 115.7 & 108.4 \\
\hline Arable land & 70,163 ha & 43,562 ha \\
\hline Distance from regional capital & $260 \mathrm{~km}$ & $410 \mathrm{~km}$ \\
\hline Production activities & 8 & \\
\hline Farming system & Northeast Mixed Cereal & $\begin{array}{l}\text { North Highland, Barley } \\
\text { and Sheep }\end{array}$ \\
\hline Major food crops & Sorghum, teff and barley & Barley, wheat and beans \\
\hline Livestock & Cattle, goat and sheep & Sheep, cattle \& horse \\
\hline Food insecure population (2009) & $42,356(40 \%)$ & $40,610(36 \%)$ \\
\hline
\end{tabular}

Source: District Agriculture and Rural Development Offices, 2013 
1

2

3

4

5

6

7

8

9

10

11

12

13

14

15

16

17

18

19

20

21

22

23

24

25

26

27

28

29

30

31

32

33

34

35

36

37

38

39

40

41

42

43

44

45

46

47

48

49

50

51

52

53

54

55

56

57

58

59

60
Table 2 - Statistics on temperature data for both districts

\begin{tabular}{llllclc}
\hline Station & Record period & MT $\left({ }^{\circ} \mathrm{C}\right)$ & OLS cof. & $\mathrm{R}^{2}$ & $\mathrm{MK}$ & $\mathrm{S}$ \\
\hline Lalibela & $1989-2011$ & Maximum & $0.0349^{* * *}$ & 0.31 & $0.333^{* * *}$ & 70 \\
(Lasta) & & & $(0.0117)$ & & & \\
& & Minimum & 0.0153 & 0.07 & 0.28 & 54 \\
& & & $(0.0121)$ & & & \\
\hline $\begin{array}{l}\text { Debark } \\
\text { (Beyeda) }\end{array}$ & & Maximum & $0.0524^{*}$ & 0.57 & $0.60^{* *}$ & 27 \\
& & & $(0.0160)$ & & & \\
& & Minimum & -0.0044 & 0.00 & 0.00 & 0.00 \\
& & & $(0.0210)$ & & & \\
\hline
\end{tabular}

Standard errors in parentheses

${ }^{*} p<0.05,{ }^{* *} p<0.01,{ }^{* * *} p<0.001$

Source: computed from NMA data.

Notes:

MT $=$ Mean Temperature

OLS cof. $=$ Ordinary Least Square coefficients that measure the effect of time on temperature.

$\mathrm{MK}=$ Kendall's tau

$\mathrm{S}=\mathrm{M}-\mathrm{K}$ test statistic or the Kendall score 
Table 3 - Statistics on rainfall data in both districts

\begin{tabular}{lllllll}
\hline Station & Record period & Season & MR $(\mathrm{mm})$ & St.Dev & CV (\%) & Trend \\
\hline Lalibela & $1989-2011$ & Belg & 122.0 & 74.6 & 61.0 & 0.12 \\
(Lasta) & & Kiremet & 547.7 & 188.9 & 34.5 & 0.04 \\
& & Annual & 713.5 & 187.5 & 26.3 & 0.00 \\
\hline Debark & $2000-2011$ & Belg & 116.3 & 62.6 & 53.9 & $0.27^{*}$ \\
(Beyeda) & & Kiremet & 933.7 & 129.5 & 13.8 & 0.01 \\
& & Annual & 1098.1 & 158.1 & 14.4 & 0.02 \\
\hline
\end{tabular}

Source: computed from meteorological data

Notes:

*Trend statistically significant using Kendall's tau at $\mathrm{p}<0.10$.

$\mathrm{MR}=$ Mean Rainfall

St. Dev $=$ Standard deviation

$\mathrm{CV}=$ Coefficient of variation (St. Dev divided by the mean)

Trend is indicated by coefficient of determination $\left(\mathrm{R}^{2}\right)$ 
Table 4 - Effects of Climate Variability and Change on Agricultural Activities in Lasta and Beyeda

\begin{tabular}{|c|c|c|}
\hline Climatic factors & Perceived impacts & Cases \\
\hline \multirow[t]{2}{*}{$\begin{array}{l}\text { Increased } \\
\text { temperature }\end{array}$} & $\begin{array}{l}\text { Increased hot and dry-spells } \\
\text { affecting crop and livestock } \\
\text { production }\end{array}$ & $\begin{array}{l}\text { Crop failure for teff, ageda-korkur (maize } \\
\text { stalk borer) affecting maize and sorghum } \\
\text { and plusia warm affecting barley and } \\
\text { sorghum in Lasta }\end{array}$ \\
\hline & $\begin{array}{l}\text { Increased pest and disease } \\
\text { incidences }\end{array}$ & $\begin{array}{l}\text { Yegebs kish-kish (barley aphid; Russian } \\
\text { wheat Aphid) affecting both crops in } \\
\text { Beyeda }\end{array}$ \\
\hline $\begin{array}{l}\text { Delay of onset of } \\
\text { rains and early } \\
\text { set-off }\end{array}$ & $\begin{array}{l}\text { Reducing length of } \\
\text { growing period }\end{array}$ & $\begin{array}{l}\text { Frequent crop failures in Lasta are } \\
\text { associated with the delay in rainfall in the } \\
\text { belg and kirmet }\end{array}$ \\
\hline Unseasonal rains & Damage to standing crops & $\begin{array}{l}\text { A few cases are reported during the dry } \\
\text { season in Beyeda }\end{array}$ \\
\hline $\begin{array}{l}\text { Increased } \\
\text { frequency and } \\
\text { magnitude of } \\
\text { drought and } \\
\text { floods }\end{array}$ & $\begin{array}{l}\text { Drought results in lack of } \\
\text { water and fodder for } \\
\text { livestock and crops. Flash } \\
\text { floods cause livestock deaths } \\
\text { can destroy homes and } \\
\text { farmland }\end{array}$ & $\begin{array}{l}\text { Droughts are more frequent in Lasta. Crop } \\
\text { pests, animal diseases, and loss of income } \\
\text { from damages to crops and livestock is } \\
\text { reported in both Lasta and Beyeda. }\end{array}$ \\
\hline
\end{tabular}

Source: Key informant interviews and group discussions, 2013 
${ }^{1}$ Key informants were purposively selected. They included: four smallholder farmers from Medage and Nakuteleeab kebeles, Lasta, and Watti and Ayiga kebeles of Beyeda. one expert from Amhara Region Food Security Coordination Office, one officer from Amhara Region Agriculture and Rural Development Office; and two PSNP coordinators from each district. Three FGDs were held, one in Beyeda and two in Lasta, involving 26 farmers. Prior to focus group discussions and key informant interviews, kebele chairpersons in each kebele suggested possible respondents.

${ }_{2}^{2}$ Injera is a staple food in many parts of Ethiopia. It is a sourdough-risen flatbread usually made out of teff, millet and/or sorghum.

${ }^{3}$ The linear regression analysis is used with time as the independent variable and temperature or rainfall as the dependent variable. This method is extensively used in climate change studies (Cheung et al. 2008; Río et al. 2011). After checking the model for the critical assumptions, the t-test (parametric test) was used to assess if the slope's coefficient of the fitted linear regression is significantly different from zero, indicating the presence of a linear trend. We used the Portmanteau test for white noise in Stata to check for autocorrelation. Maximum temperature data from both districts have passed this test showing no serial correlation. These data also passed the Breusch-Pagan / Cook-Weisberg test for heteroskedasticity. Following Yue and Hashino (2003), the nonparametric (distribution free) Mann-Kandall (M-K) test has also been applied to assess the significance of monotonic trend. The test also confirmed the existence of significant upward trends in annual mean maximum temperature in the two districts.

${ }^{4}$ According to figures obtained from the district Agriculture and Rural Development Office, there were about 1237 participants in training activities in 2013. 
1

2

3

4

5

6

7

8

9

10

11

12

13

14

15

16

17

18

19

20

21

22

23

24

25

26

27

28

29

30

31

32

33

34

35

36

37

38

39

40

41

42

43

44

45

46

47

48

49

50

51

52

53

54

55

56

57

58

59

60

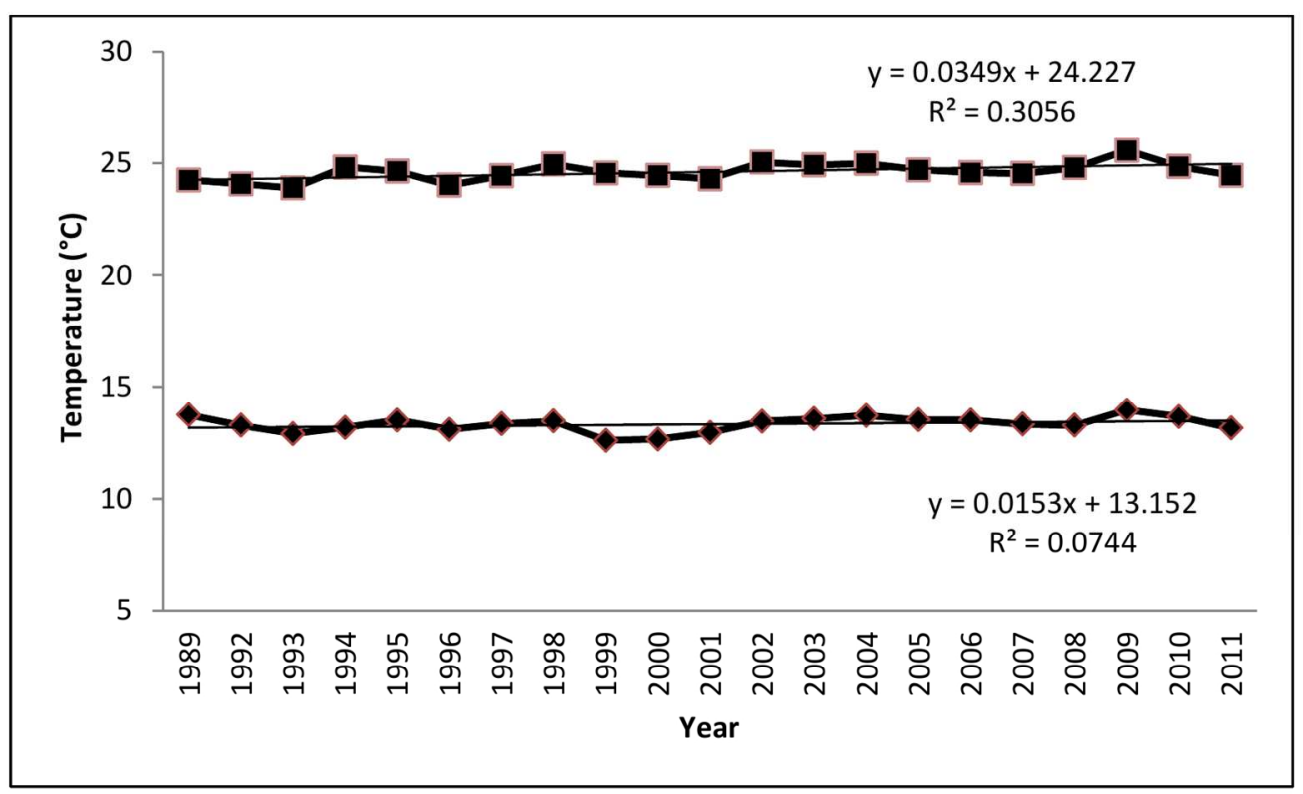

$142 \times 86 \mathrm{~mm}(300 \times 300$ DPI $)$ 


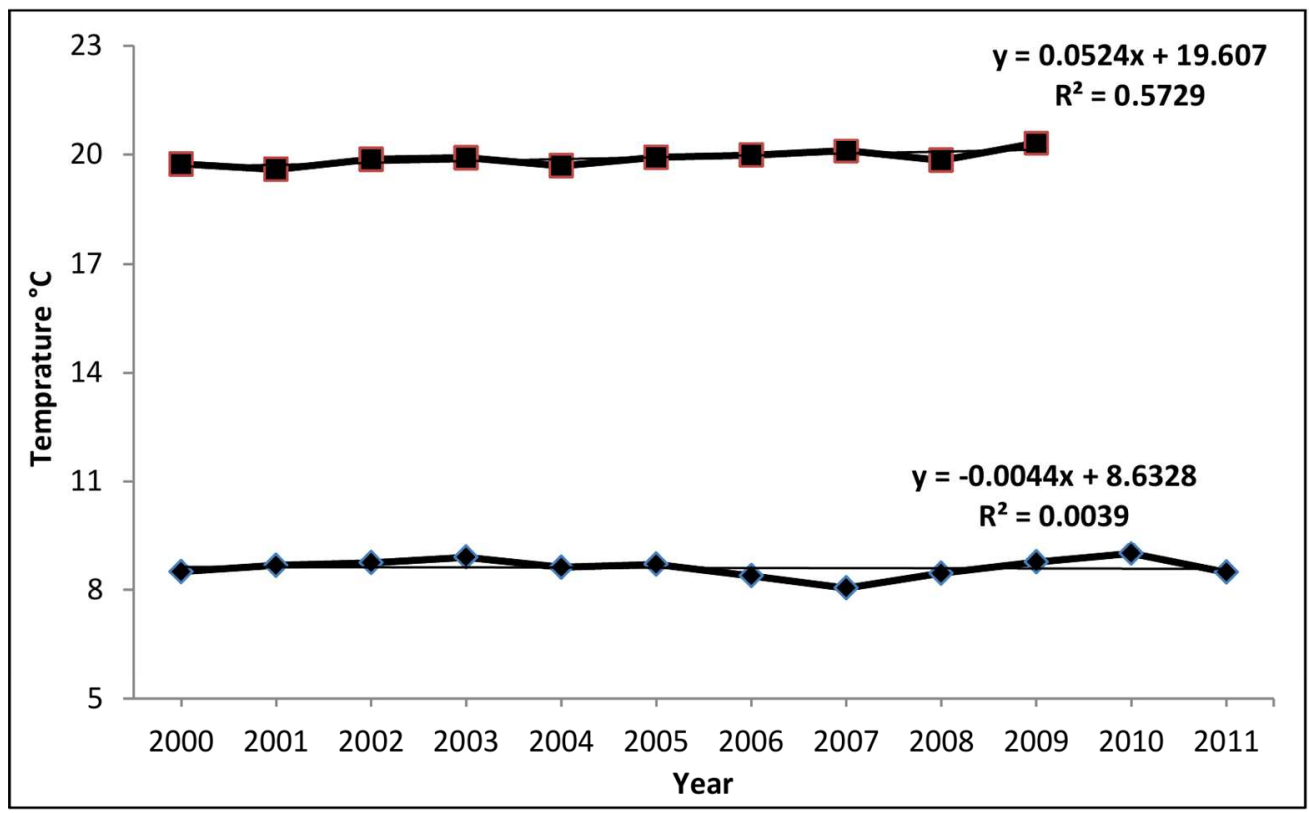

$140 \times 86 \mathrm{~mm}(300 \times 300$ DPI $)$ 


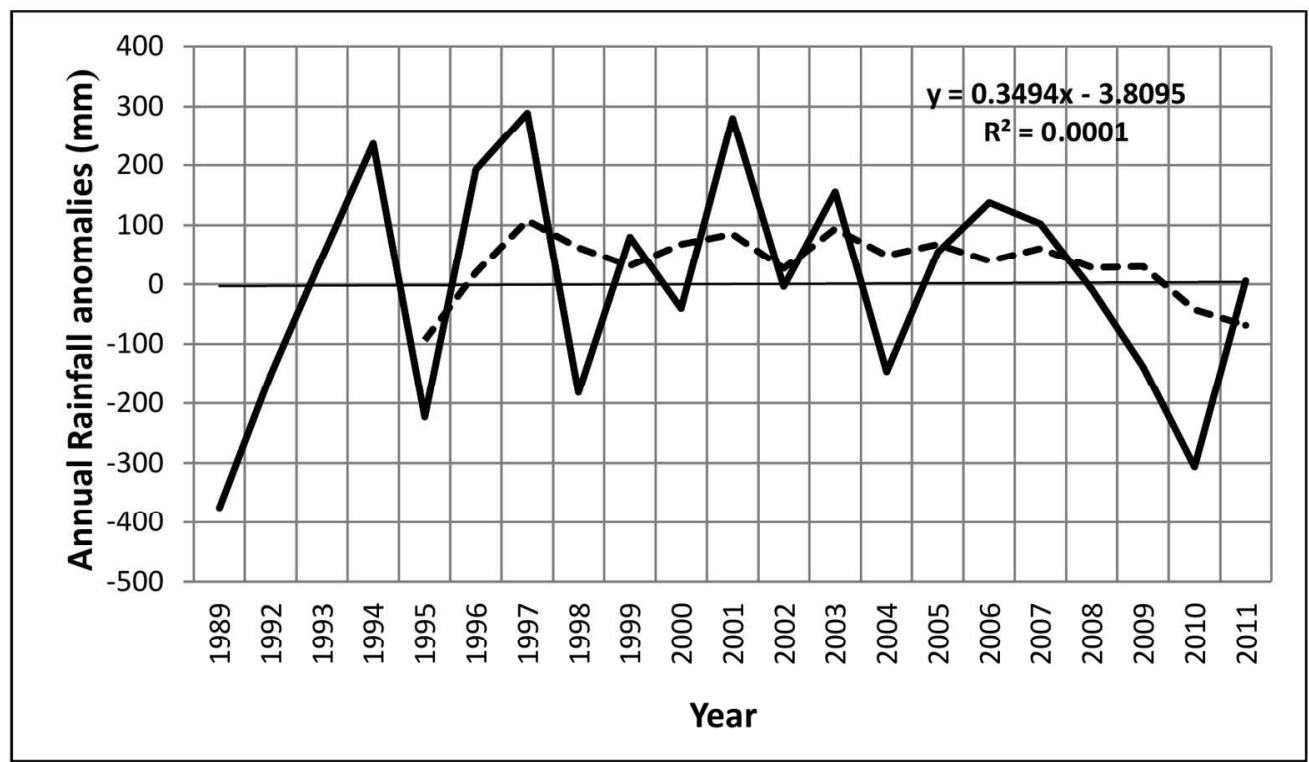

$145 \times 85 \mathrm{~mm}(300 \times 300 \mathrm{DPI})$ 


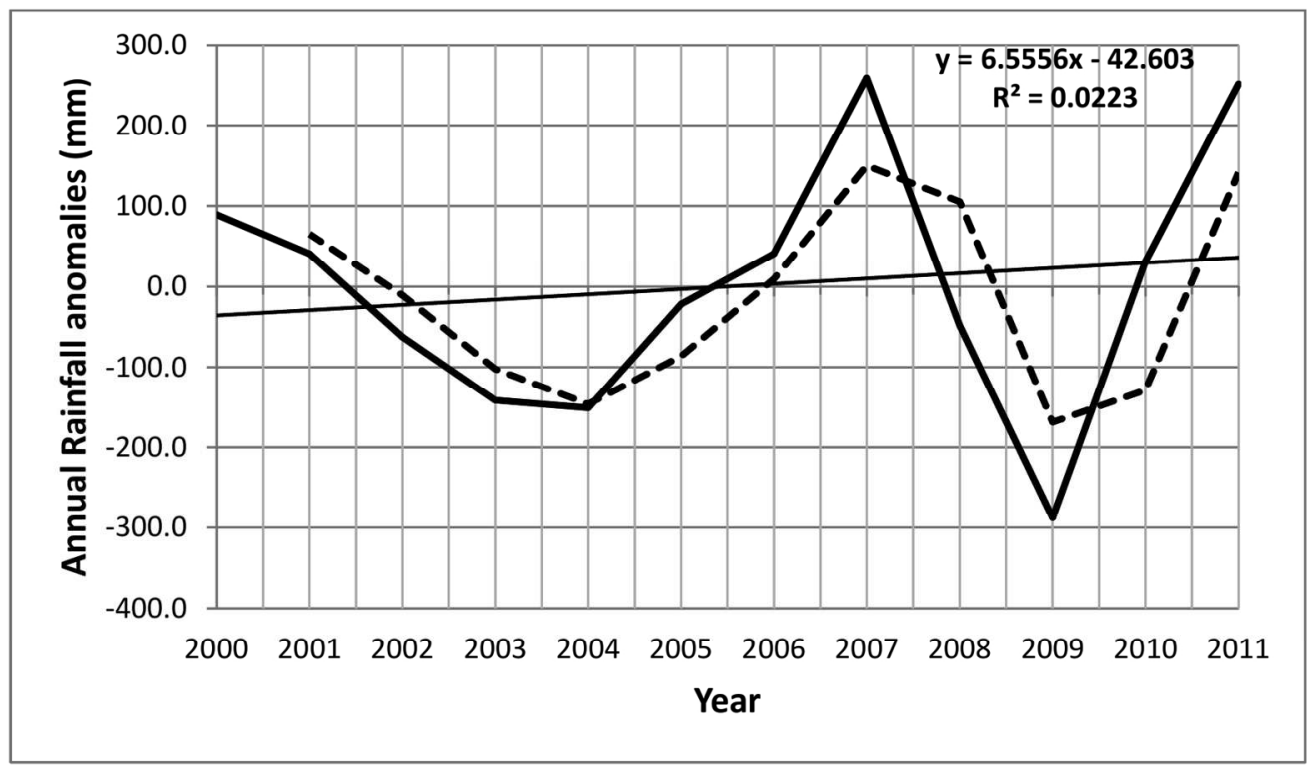

$145 \times 84 \mathrm{~mm}(300 \times 300 \mathrm{DPI})$ 